\title{
RELATIONSHIP BETWEEN PERSONAL CHARACTERISTIC WITH KNOWLEDGE OF ANTIBIOTIC USAGE IN MEDAN CITY
}

\author{
RINA AMELIA ${ }^{1 *}$, JULIANDI HARAHAP ${ }^{1}$, ARLINDA SARI WAHYUNI ${ }^{1}$, ARIEF PRATAMA ${ }^{2}$ \\ ${ }^{1}$ Department of Public Health, Faculty of Medicine, Universitas Sumatera Utara, Jl. Dr. Mansyur No.5, Kampus USU, Medan 20155, \\ Indonesia. ${ }^{2}$ Medical Student of Faculty of Medicine, Universitas Sumatera Utara, Jl. Dr. Mansyur No.5, Kampus USU, Medan 20155, \\ Indonesia. Email: drrinaamelia@gmail.com
}

Received: 06 December 2017, Revisedand Accepted: 14 February 2018

ABSTRACT

Objective: The objective of this research is to analyze the relationship between personal characteristics with knowledge of antibiotics usage in Medan.

Methods: This research is an analytic research with cross-sectional approach. The data collection process was conducted in November 2013. The study population is the people residing in the district of Medan Johor; subjects are 336 people which enrolled by consecutive sampling technique. The data were obtained by interview using questionnaires that have been tested for validity and reliability. Data analysis was done using Chi-square statistical test using SPSS program.

Results: The results showed that the level of knowledge of the Johor subdistrict community on the antibiotic usage was in the good category (79.5\%). The statistical analysis showed that there was a statistically significant relationship between education level with knowledge of antibiotic usage $(p<0.05)$. There was no relationship between sex and age with knowledge of antibiotic usage.

Conclusion: Knowledge is the main factor and has an important role which every patient should have so that they can take antibiotics appropriately. To increase the public's knowledge about the proper use of antibiotics, it is desirable that the role of physicians give a role in communicating them to the patients so that the use of antibiotics can be done appropriately.

Keywords: Knowledge, Antibiotic usage, Educational level, Age, Gender.

(c) 2018 The Authors. Published by Innovare Academic Sciences Pvt Ltd. This is an open access article under the CC BY license (http://creativecommons. org/licenses/by/4. 0/) DOI: http://dx.doi.org/10.22159/ajpcr.2018.v11s1.26601

\section{INTRODUCTION}

Antibiotics are an important drug used in the treatment of bacterial infections [1]. The use of rational antibiotics, referring to the accuracy of the dosage, the selection of antibiotics, and the dosage form that should be given to the patient [2]. More than half of patients in hospital care receive antibiotics as a treatment or prophylaxis. About $80 \%$ of antibiotic consumption is used for human benefit and at least $40 \%$ based on inappropriate indications such as viral infection. The use of irrational antibiotics may lead to increased health financing, side effect risks, prolonged treatment, decreased or loss of bacterial sensitivity to antibiotics, and risk of bacterial resistance $[3,4]$.

According to the WHO data, Indonesia ranks $8^{\text {th }}$ out of 27 countries in the world with high resistance to antibiotics [5]. This is because there is still a lack of awareness and public knowledge about the proper use of antibiotics so that $92 \%$ of Indonesians use antibiotics improperly [6]. Among others are ampicillin (34\%), cotrimoxazole (29\%), and chloramphenicol (25\%). Other results indicate the incidence of antibiotic resistance as found by antimicrobial resistance in Indonesia (AMRIN study) which studied 2494 subjects to see the sensitivity of Escherichia coli to antibiotics; the result showed that $43 \%$ Escherichia coli resistant to various types of antibiotics. Antibiotic resistance has become a problem around the world.

There are several factors that influence the proper use of antibiotics in the community. One important factor is the level of public knowledge about antibiotics itself. Several factors affect the level of knowledge, such as the level of education from the community, doctors explanations, and other assumptions that cause errors when taking antibiotics $[6,7]$. The rational use of antibiotics should be based on the knowledge about antibiotics that physicians and pharmacists can provide about pharmacological effects, side effects, drug interactions, and use instructions. Such information is the basis for patients in using antibiotics rationally. In addition, information from physicians and pharmacists is also required to support patient compliance in rational use of antibiotics [8].
The level of public knowledge in the use of antibiotics has been studied in various regions. Research conducted by Lim and Tea [9] in Putrajaya, Malaysia, mentioned that $83 \%$ of respondents did not know that antibiotics did not work against viral infections and $82 \%$ of respondents did not know that antibiotics could not treat coughs and flu, while $82.5 \%$ of respondents were seen be very careful with the use of antibiotics that can cause allergies. The study also stated that about half of them $(52.1 \%)$ did not know that antibiotics can cause many side effects. Some statements from respondents were no problem stopping the use of antibiotics when symptoms have been improved and taking a less amount of antibiotics from the doctors' prescription will be healthier than consuming all prescribed antibiotics. The level of community knowledge is also influenced by such levels of education from the community, doctors explanations, as well as other assumptions that cause errors when taking antibiotics $[6,7]$. The objective of the study was for the relationship between personal characteristic with knowledge of antibiotic usage in Medan city.

\section{METHODS}

The design of this research is analytic with cross-sectional approach. The data collection process was conducted in November 2013 in Medan Johor district, Medan city. The population of this research is the people residing in Johor subdistrict of Medan, the sample of 336 subjects with the consecutive sampling technique. Data collection was done by interview using questionnaires that have been tested for validity and reliability. Community participation is voluntary and they have previously signed informed consent. Data analysis was done using Chisquare statistical test by SPSS program.

\section{RESULTS}

Table 1 shows that the majority of respondents gender is women 207 people (61.6\%), by age groups show that the most age groups in this study are $>45$ years old as many as 107 people $(31.8 \%)$, based on education level it was showed that the majority of respondents had 
medium level of education (45.2\%), the most involved group in the research worked as housewife as many as 100 subjects (31.0\%).

Table 2 summarized that the majority of respondents' knowledge about antibiotics is good as much as 267 respondents (79.5\%).

Table 3 summarized that female had the highest level of knowledge as many as 170 respondents (63.7\%), the level of knowledge is the higher among respondents who have medium education level of 133 people (49.8\%), the age group $>45$ years had better knowledge level as many as 91 people (34.1\%). Chi-square test showed that there was correlation between education level and knowledge $(p<0.05)$ while

Table 1: Distribution of respondent characteristics

\begin{tabular}{ll}
\hline Characteristics & Frequency (people) (\%) \\
\hline Gender & $129(38.4)$ \\
Man & $207(61.6)$ \\
Woman & \\
Age group (year) & $31(9.2)$ \\
15-19 & $33(9.8)$ \\
$20-24$ & $25(7.4)$ \\
$25-29$ & $51(15.2)$ \\
$30-34$ & $40(11.9)$ \\
$35-39$ & $49(14.6)$ \\
$40-44$ & $107(31.8)$ \\
$>45$ & $91(27.1)$ \\
Level of education & $152(45.2)$ \\
Low (elementary) & \\
Medium (junior and senior & $93(27.2)$ \\
high school) & $100(31.0)$ \\
High (college) & $80(6.0)$ \\
Occupation & $89(10.0)$ \\
Housewife & $40(20.0)$ \\
Civil servant & $27(33.0)$ \\
Private employee & \\
Entrepreneur & \\
Retired &
\end{tabular}

Table 2: Frequency distribution of knowledge level of respondents

\begin{tabular}{ll}
\hline Knowledge level & Frequency (people) (\%) \\
\hline Good & $267(79.5)$ \\
Medium & $48(14.3)$ \\
Less & $21(6.3)$ \\
Total & $336(100)$ \\
\hline
\end{tabular}

Table 3: Relationship between characteristics with knowledge level

\begin{tabular}{|c|c|c|c|c|c|c|c|}
\hline \multicolumn{8}{|c|}{ Knowledge level } \\
\hline \multirow[t]{2}{*}{ Characteristic } & \multicolumn{2}{|l|}{ Good } & \multicolumn{2}{|c|}{ Medium } & \multicolumn{2}{|c|}{ Less } & \multirow[t]{2}{*}{$\mathbf{p}$} \\
\hline & n (\%) & & n $(0$ & & n $(0$ & & \\
\hline Gender & & & & & & & 0.192 \\
\hline Man & 97 & 36.3 & 22 & 45.8 & 10 & 47.6 & \\
\hline Woman & 170 & 63.7 & 26 & 54.2 & 11 & 52.4 & \\
\hline \multicolumn{8}{|l|}{ Age group } \\
\hline $15-19$ & 20 & 7.5 & 10 & 21 & 1 & 4.8 & 0.234 \\
\hline $20-24$ & 27 & 10.1 & 3 & 6.2 & 3 & 14.3 & \\
\hline $25-29$ & 21 & 7.9 & 3 & 6.2 & 1 & 4.8 & \\
\hline $30-34$ & 43 & 16.1 & 6 & 12.5 & 2 & 9.5 & \\
\hline $35-39$ & 30 & 11.2 & 6 & 12.5 & 4 & 19.1 & \\
\hline $40-44$ & 35 & 13.1 & 11 & 22.9 & 3 & 14.3 & \\
\hline$>45$ & 91 & 34.1 & 9 & 18.7 & 7 & 33.3 & \\
\hline $\begin{array}{l}\text { Level of } \\
\text { education }\end{array}$ & & & & & & & 0.0001 \\
\hline Low & 48 & 18 & 26 & 54.2 & 17 & 80.9 & \\
\hline Medium & 133 & 49.8 & 16 & 33.3 & 3 & 14.3 & \\
\hline High & 86 & 32.2 & 6 & 12.5 & 1 & 4.8 & \\
\hline
\end{tabular}

there was no correlation between age and sex with knowledge about antibiotics $(\mathrm{p}>0.05)$.

\section{DISCUSSION}

In general, the level of knowledge of the people of Medan Johor district is in the good category. The results of this study are in accordance with the results of Pulungan [10] and You et al. [11] found that the majority of people's knowledge of antibiotics is good (77\% and $70 \%)$, but this study is not in line with the research done by Ling Oh et al. [12] that the majority of respondents' knowledge is quite $54.7 \%$. And by Larson et al. [13] gained low responders' knowledge of antibiotics of $61.1 \%$.

Based on Chi-square test, there is correlation between knowledge level and education level $(\mathrm{p}<0.05)$ and there is no correlation between age and gender with respondent knowledge about antibiotic $(p>0.05)$. The results of this study are in line with the research conducted by Toraya et al. [14] which found that the level of education affect the public knowledge about antibiotics, while the age and gender does not affect the level of public knowledge. Larson et al. found the similar result [13]. There was a relationship between education level and the respondent's knowledge about antibiotics, while sex has no relationship with the level of knowledge. According to Notoatmodjo [15], there are several factors that affect the level of one's knowledge, information gained, social, cultural, economic, environmental, experience, and age. A person's mindset will be appropriate to his or her level of education because education can impact on a person's ability to receive information and this information can affect his or her knowledge [15]. In Baumann and Koos's opinion, the more educated a person, the better his knowledge of health and vice versa [16].

\section{CONCLUSION}

There is a compelling relationship between the level of education and the knowledge about antibiotics in the community in Johor district, the provision of knowledge by health workers can reduce the use of irrational antibiotics in society so as to prevent the occurrence of resistance.

\section{REFERENCES}

1. The Antibiotic Awareness Campaign. National Health Study Choices. Available from: http://www.nhs.uk. [Last assessed on 2013 mar 30].

2. WHO. Medicine: Rational Use of Medicines. World Health Organization Media Centre. Available from: http://www.who.int. [Last assessed on 2013 Mar 31].

3. Qibtiyah M. Sustained Pharmacy Education Papers XXV: Use of Antibiotics: The Impact of Antibiotic use on Resistance. Surabaya: BPD ISFI East Java, Faculty of Pharmacy University of Airlangga; 2005.

4. Azevedo MM, Pinheiro C, Yaphe J, Baltazar F. Portuguese students' knowledge of antibiotics: A cross-sectional study of secondary school and university students in Braga. BioMed Central 2009;9:1-6.

5. Ministry of Health of the Republic of Indonesia. Antibiotics Resistance. Available from: http://www.depkes.go.id. [Last assessed on 2013 Mar 31].

6. Larasari P. The Effect of Antibiotics Counseling and Leaflet Media in Patrang Community Jember District. Jember: Repository Unejn; 2015.

7. Krisdianto BD, Tamayanti WD, Soegiarto EV. Exploration of factors that affect the use of antibiotics in pharmacies k24 wiyung and Karah Agung Surabaya. Widya Med J 2014;2:82-7.

8. Akici A, Kalaca S, Ugurlu MU, Toklu HZ, Iskender E, Sule O. Patient knowledge about drugs prescribed at primary healthcare facilities. Pharm Epidemiol Drug Saf 2004;13:871-6.

9. Lim KK, Teh CC. A cross sectional study of public knowledge and attitude towards antibiotics in Putrajaya, Malaysia 2012. South Med Rev 2012;5:26-33.

10. Pulungan S. Level of Knowledge Relationship on Antibiotics and Its Use in Non-Medical Students of North Sumatera University. USU Institutional Repository; 2011. Available from: http://www.repository. usu.ac.id/handle/123456789/25623. [Last assessed on 2013 May 15].

11. You JH, Yau B, Choi KC, Chau CT, Huang QR, Lee SS, et al. Public knowledge, attitudes and behavior on antibiotic use: A telephone survey in hong kong. Infection 2008;36:153-7.

12. Ling Oh A, Hassali MA, Al-Haddad MS, Syed Sulaiman SA, 
Shafie AA, Awaisu A, et al. Public knowledge and attitudes towards antibiotic usage: A cross-sectional study among the general public in the state of Penang, Malaysia. J Infect Dev Ctries 2011;5:338-47.

13. Larson EL, Cohen B, Ross B, Behta M. Isolation precautions for methicillin-resistant Staphylococcus aureus: Electronic surveillance to monitor adherence. Am J Crit Care 2009;19:16.
14. Toraya NA, Dewi MK, Susanti Y. Relation of Education Level and Economic Status to Knowledge Level about Antibiotic Usage. Proc Doct Educ 2015:91-6.

15. Notoatmodjo S. Health Promotion and Behavioral Science. Jakarta: PT. Rineka Cipta; 2007. p. 86.

16. Friedman M. Nursing Family. $3^{\text {rd }}$ ed. Jakarta: EGC; 1998 